\title{
Developing Performance Assessment Instruments to Evaluate the Competence Achievement in Patisserie Learning
}

\author{
M. G. Mirani \\ Home Economic Education Department \\ Engineering Faculty, The State University of Surabaya \\ Surabaya-Indonesia \\ maurengoitta@yahoo.com
}

\author{
Ana \\ Home Economic Education Department \\ Faculty of Technology and Vocational Education \\ Universitas Pendidikan Indonesia \\ ana_syarief@yahoo.co.id
}

\begin{abstract}
The lack of standardized assessment instruments which can assess student achievement competence in learning patisserie made the researchers motivated to create it. The purpose of this study is to create the design of assessment instrument which can be applied in teaching patisserie. This study used Developmental Research method. The development of performance assessment instrument consists of assessment indicators and assessment rubric. The development of assessment indicators must refer to the patisserie learning curriculum, which is the standard competence in "Making Bread Products" and the basis of competence in "Making Hard Roll and Soft Roll Bread". The samples of this study were the eleventh graders and the subject teachers of SMK Negeri 9 Bandung, East Java. This study was conducted into two steps: (1) the preliminary stage, which consists of the identification problem, and (2) the formative evaluation stage, which consists of assessment theory, constructing the initial design model of instrument and rubrics, validation and revision, limited testing, and making report. The content and evaluation experts had validated well the assessment indicators to be used in field test. The results showed that the performance assessment instrument was suitable for assessing the student achievement competence and assisting teachers in assessing student achievement.
\end{abstract}

Keywords - assessmen, performance assessment, competency, patisserie

\section{INTRODUCTION}

Vocational high school is the sub-system from national education that is experiencing a change for the sake of improvement and enhancement of the quality of the education. Consummation and improvement of secondary vocational education is done in order to anticipate the needs and challenges in the future. This needs to be constantly carried out, are aligned with the needs of the development of the business world and the industrial world, the world of work, as well as science and technology. Vocational high school (SMK) is an intermediate level vocational education under the construction of Vocational secondary education Directorate (Ditdikmenjur), which prepares graduates to work in a particular field armed with knowledge, skills and attitude to work in accordance with the needs of the business world and the world of industry or entrepreneurship. The system of education in SMK very strives to increase the skills and expertise of human resources developed based on competence. The education system is based on the competencies sought in order for the output of an institution of vocational education have the skills and expertise that are relevant to the needs of the world of work. In line with this, then the curriculum used CMS vocational schools is Curriculum unit level education (KTSP) that characterize its paradigm is a competency-based development that will include the syllabus and assessment system.

The assessment process in KTSP is conducted by classroom-based assessment which is one of the components in the competency-based curriculum, is essentially an assessment activity are kept integrated in teaching and learning activities (Department of national education, 2002). Classroom-based assessment is conducted to provide continuity on the third realm of cognitive, affective, and psychomotor by using various forms of assessment models and officially or unofficially with sustainability.

Assessment of learning outcome become the problems, that need to be considered. In carrying out the assessment of learning outcome at school there is tendency of teachers to give priority to the use of tests (paper and pencil test) as the only important measurement tool in the process of education. These conditions encourage excessive use of tests to measure all the planned learning objectives. Even though the test itself has its limitations, among other things: (1) not being able to measure the actual learners capabilities, (2) the test only focused on final score and did not focus on how students obtain answers, and (3) only focused on some aspects of the course (Sa'dijah, 2009). This test also does not give the opportunity to students to show the ability or potential of each.

The most appropriate type of assessment to be applied at vocational schools is the performance appraisal or performance assessment. As summarized by Setiyadi (2009) performance 
appraisal or performance assessment considered the assessment of the learning outcomes that are better than the assessment with tests by most educators with an understanding that performance assessment is the assessment that is closer to reality the ability to learn. The use of performance assessment to assess the students gives more ability and the opportunity to students to be involved in the learning process. With this performance assessment, expected learning outcomes measurement process is no longer considered to be an activity that is not attractive and not a separate part of the learning process. Therefore the use of the performance assessment becomes important in the learning process, because it can provide more information about the capabilities of the learners in the process nor product, not just to obtain information about the right or wrong answer only. On the basis of this performance assessment of the use of the paper and pencil test is the urgent needs to be developed in the process of learning and assessment that meets national standards of education.

There is a problem that researchers found in a field, i.e., based on observations made by researchers at SMK Negeri Bandung 9 still awaited the implementation assessment process which only deals with the cognitive aspects of evaluation tools to be a written test. Whereas the characteristic of Patisserie learning not only involves the cognitive aspects, but also involves aspects of affective and psychomotor. Starting from dotted background presented then focus this research deals with the development of a performance assessment instrument in Patisserie learning.

\section{RESEARCH METHOD}

This research was conducted to generate the appropriate assessment instruments applied in Patisserie learning. In accordance with the research objectives and the problem in this research, then the method used in this research is Development Research methods (DR), its adopted from Akker (1999). The steps undertaken, namely; (1) identify the problem assessment competency attainment of students, (2) reviewing the theory about the development of the instrument, (3) make the first design of the instruments performance assessment, (4) early design validation instrument, (5) a limited trial, (6) revision of the design and make a report.

The subject in this research is consists of two teachers model and 38 students. The teacher's model is the teacher of patisserie subjects in SMK Negeri Bandung 9. The trials in this research is limited trial is done by using the results of development (the competence is Make a soft roll and hard roll) directly learning in the classroom.

Data obtained from the entire stage in this research is quantitative data is a number 0 or 1 , and the qualitative data in the form of validation results, suggestions, comment and limited trials. The questionnaire that used in this research is the questionnaire for validator and validation response sheet teacher performance assessment model results against development. Feasibility of the product development research is determined by the validator which consisted of three people, namely the expert field of learning evaluation, expert of patisserie field, and lecturer from patisserie's department.
Product of this development research is declared feasible with revised first..

\section{RESULTS}

The result of this research in the form of research data obtained from variety ways during the studies by following all the procedures that exist. This research resulted in findings regarding: 1) what are the dimensions should be assessed in performance assessment instrument on the competency of skills Patisserie, 2) the assessment rubric, and 3) an overview of the practicality of the use of performance assessment instruments development results.

TABLE I. INDICATORS OF PERFORMANCE ASSESSMENT INSTRUMENT

\begin{tabular}{|c|c|c|}
\hline Indicators & Sub-indicators & Criteria \\
\hline \multirow[t]{5}{*}{$\begin{array}{l}\text { Work's } \\
\text { preparations }\end{array}$} & $\begin{array}{l}\text { Occupational health } \\
\text { and safety people }\end{array}$ & $\begin{array}{l}\text { Students wear the double } \\
\text { breast black pants non } \\
\text { pair of jeans, an apron, } \\
\text { slayer, hat cook, shoes, } \\
\text { maintaining the } \\
\text { cleanliness of nails, } \\
\text { washing the hands before } \\
\text { and after work, and not } \\
\text { lifting goods which } \\
\text { weighs beyond the ability }\end{array}$ \\
\hline & $\begin{array}{lr}\text { Occupational } & \text { health } \\
\text { and safety } & \text { tools } \\
\text { equipment } & \end{array}$ & $\begin{array}{l}\text { Students cleaning the } \\
\text { tools equipment before } \\
\text { and after cook, using tools } \\
\text { in accordance with its } \\
\text { function, operates and } \\
\text { storing tools correctly }\end{array}$ \\
\hline & $\begin{array}{l}\text { Occupational health } \\
\text { and safety the food }\end{array}$ & $\begin{array}{l}\text { Students use opening the } \\
\text { box/wrap food properly, } \\
\text { composing heavy stuff in } \\
\text { the bottom, not speak to } \\
\text { people when cook, and } \\
\text { not scratching and } \\
\text { coughing for touched food }\end{array}$ \\
\hline & $\begin{array}{l}\text { Occupational health } \\
\text { and safety the kitchen } \\
\text { area }\end{array}$ & $\begin{array}{l}\text { Students keep workspace } \\
\text { to be in a state of clean, } \\
\text { do not leave the kitchen } \\
\text { before know that stove, } \\
\text { lights, gas and electricity } \\
\text { have turned off, students } \\
\text { do not smoke in the room } \\
\text { work, killing the lights not } \\
\text { used, to clean material } \\
\text { that is spilled/the floor } \\
\text { slippery }\end{array}$ \\
\hline & Work's plan & $\begin{array}{l}\text { Students planning } \\
\text { material composing, tools } \\
\text { equipments which will be } \\
\text { used, orderly work, } \\
\text { calculations a charge of } \\
\text { the manufacture and the } \\
\text { selling price of the } \\
\text { product }\end{array}$ \\
\hline \multirow[t]{3}{*}{ Work process } & Sistematic work & $\begin{array}{l}\text { Students work according } \\
\text { to a work's step, use } \\
\text { energy and materials } \\
\text { efficiently and not } \\
\text { wasting time }\end{array}$ \\
\hline & $\begin{array}{l}\text { The way to make a } \\
\text { dough }\end{array}$ & $\begin{array}{lll}\text { Students weighing } & \text { and } \\
\text { mixing, kneading } & \text { and } \\
\text { fermenting dough } & \\
\end{array}$ \\
\hline & How to shaping a & Students divide and weigh \\
\hline
\end{tabular}




\begin{tabular}{|c|c|c|}
\hline Indicators & Sub-indicators & Criteria \\
\hline & dough & $\begin{array}{l}\text { the dough, shaping the } \\
\text { dough, formed in } \\
\text { accordance with the type } \\
\text { of bread }\end{array}$ \\
\hline & $\begin{array}{l}\text { How to cultivate a } \\
\text { dough }\end{array}$ & $\begin{array}{l}\text { Students processing } \\
\text { products with the method } \\
\text { according to the standard } \\
\text { recipe, ferment, and bake } \\
\text { the dough with a standard } \\
\text { recipe and process the } \\
\text { product correctly and } \\
\text { carefully }\end{array}$ \\
\hline \multirow[t]{5}{*}{ Product } & Shape & $\begin{array}{l}\text { Bread has a perfect } \\
\text { (fluffy and inflate), the } \\
\text { form of bread according } \\
\text { to standard forms and a } \\
\text { types of bread, bread has } \\
\text { uniform size, light and } \\
\text { tidy }\end{array}$ \\
\hline & Colour & $\begin{array}{l}\text { the color over the surface } \\
\text { is golden brown, the } \\
\text { results of baking is } \\
\text { flattened, bread crust } \\
\text { according to type }\end{array}$ \\
\hline & Taste & $\begin{array}{l}\text { The taste of bread } \\
\text { according to the standard } \\
\text { type of the bread }\end{array}$ \\
\hline & Texture & $\begin{array}{l}\text { Texture of the bread } \\
\text { according to the standard } \\
\text { of bread }\end{array}$ \\
\hline & Serve the product & $\begin{array}{l}\text { Students serve the bread } \\
\text { with the type of product, } \\
\text { use equipment or place in } \\
\text { accordance with the type } \\
\text { of bread, laid out of the } \\
\text { bread in accordance with } \\
\text { the usebility and the } \\
\text { opportunities in } \\
\text { accordance with the basic } \\
\text { principle the arrangement } \\
\text { / food display, and } \\
\text { managing the bread by } \\
\text { pulling and tidy }\end{array}$ \\
\hline Time & Time management & $\begin{array}{l}\text { Students work with time } \\
\text { determined }\end{array}$ \\
\hline \multirow[t]{3}{*}{ Work attitude } & Responsibility & $\begin{array}{l}\text { The characteristics hard } \\
\text { work, always use his } \\
\text { ability in its own work, } \\
\text { responsible for his work } \\
\text { which handled with } \\
\text { finished on time, have } \\
\text { with the objective in } \\
\text { work, independent } \\
\text { consciousness will work } \\
\text { that handled }\end{array}$ \\
\hline & $\begin{array}{l}\text { The desire of } \\
\text { achievement }\end{array}$ & $\begin{array}{l}\text { The urge to success, } \\
\text { always want feedback on } \\
\text { their work and use it as an } \\
\text { opportunity to self- } \\
\text { evaluation, have the desire } \\
\text { compete in a good manner } \\
\text { with himself or others, to } \\
\text { be able to make a } \\
\text { breakthrough in thinking }\end{array}$ \\
\hline & Self-development & $\begin{array}{l}\text { With self-supporting the } \\
\text { urge to move forward to } \\
\text { become better and always } \\
\text { experienced an increase } \\
\text { during the lesson }\end{array}$ \\
\hline
\end{tabular}

\begin{tabular}{|l|l|l|}
\hline Indicators & \multicolumn{1}{|c|}{ Sub-indicators } & \multicolumn{1}{c|}{ Criteria } \\
\hline & Independence & $\begin{array}{l}\text { Always do their work by } \\
\text { theirselves and did not } \\
\text { depend on the others in to } \\
\text { complete the task of his } \\
\text { job, and like challenges }\end{array}$ \\
\hline
\end{tabular}

Revisions aims to get a product produced get better. Revisions done with reference to a criterion the product and expert advice or comments ( validator ) and teachers model.The draft instrument of the result of developing is mainly were revised in terms of the arrangement. As for part the draft an instrument that experienced revision in detail served in this table 2 .

TABLE II. THE INSTRUMENT'S REVISION OF THE RESULT OF DEVELOPING BASED ON VALIDATION AND LIMITED TRIAL

\begin{tabular}{|l|l|}
\hline \multicolumn{1}{|c|}{ The Development } & \multicolumn{1}{|c|}{ Improvement Result } \\
\hline Assessment & $\begin{array}{l}\text { Indicators work processes need to be fitted } \\
\text { with products that will be judged, in this case } \\
\text { is a product bakery. } \\
\text { Preparing assessment indicators should contain } \\
\text { cognitive domain, affective, and psikomor, } \\
\text { how much more work attitude must contained } \\
\text { in newsroom assessment }\end{array}$ \\
\hline Criteria of indicators & $\begin{array}{l}\text { The sentence have to use the uniform verb } \\
\text { (using active or passive verb) so it will not } \\
\text { confusing marker. } \\
\text { The indicators of the criteria is adapted to the } \\
\text { type of product that will be made. } \\
\text { Avoid the use of the word-rich that cannot be } \\
\text { measured, such as "good" and "right". }\end{array}$ \\
\hline Point scale & $\begin{array}{l}\text { In assessing avoid order form assessment } \\
\text { range number (e.g. , 1,2,3,4). }\end{array}$ \\
\hline
\end{tabular}

After developing the indicators and sub-indicator of performance assessment instrument to assess the achievements of the competency, the next step is to develop the assessment rubric and conform with an instrument performance assessment that has been made. This is the table of rubric result of development:

TABLE III. THE ASSESSMENT RUBRIC

\begin{tabular}{|l|l|}
\hline $\begin{array}{c}\text { Achievement level } \\
\text { (score) }\end{array}$ & \multicolumn{1}{|c|}{ Note } \\
\hline Special (4) & $\begin{array}{l}\text { Goals/competencies can be achieved fully and growth } \\
\text { students is aimed to achieve their aims. }\end{array}$ \\
\hline Good (3) & $\begin{array}{l}\text { Most of the goal/competency be used with good } \\
\text { growth and students be directed to achieve their aims. }\end{array}$ \\
\hline Enough (2) & $\begin{array}{l}\text { Only a small competencies that can be achieved } \\
\text { students and the growth students are more focused on } \\
\text { the achievement in order }\end{array}$ \\
\hline Less (1) & $\begin{array}{l}\text { There is not a signs with the objective/competency } \\
\text { that is expected }\end{array}$ \\
\hline
\end{tabular}

The result of observation, an interview, and examine theory to introduction's study to know needs early learning, can be 
described the image design instrument performance assessment that is required by teachers to assess its achievements competency. Results of the analysis is a basis development performance assessment instruments that will be used in evaluation, and will make it easier for teachers in assessing student's competence because its achievements sheets assessment was accompanied by the rubric assessment and how to make an objective evaluations.

From the results testing also found that by using an instrument performance assessment as many as two times in every basic competency, the ability of the students can be increased. The use performance assessment in learning activity, cam make students are more active, because the involvement and students activity in the teaching will be more motivated students to understanding the learning materials.

Instrument performance assessment, result of the development made student's assessment to evaluate the competence to be clear, objective (not subjective), and with clear scoring the values can be the accountability responsibility. In addition, give feedback with result of the evaluation competency themselves to the students about the acquisition values, the students to know what the weakness of the weakness so it is expected to eventually students are able to enhance and improve competency.

\section{CONCLUSION}

This research is results an evaluation sheet, namely performance assessment instrument and It can use in patisserie learning. The developing of the instrument are (1) the assessment indicators, (2) criteria of the indicators, and (3) rubrics. From the results of observation, interviews, and review of the theory on a introductory study to find out the needs of early learning, can be described an overview of performance assessment instruments design required by the teacher to assess the competence. The results of the analysis are the basis of the development of a performance assessment instruments to be used in the evaluation, and will facilitate teachers in assessing of the students, because the assessment sheet was accompanied with assessment and rubric scoring that way to its objective. From the results of the tests also found that by using the instruments performance assessment on every competencies, the ability of the students can be increased. The use of performance assessment in the learning activities can make students more active, due to the involvement and liveliness in learning will further motivate the students in understanding the learning material. Performance assessment instrument also make student assessment become clear, objective rather than subjective, and by scoring a clear value can also be accountable. In addition by providing visual feedback of competence evaluation results to the students about the acquisition value, students become know their weakness, so hopefully later students can enhance and improve competencies.

\section{REFERENCES}

[1] Ana. (2011). Pengembangan Model Pembelajaran Patiserie Berbasis Proyek Pada Keahlian Tata Boga. Disertasi : Universias Negeri Yogyakarta. Tidak diterbitkan.

[2] Hutabarat, O. R. (2004). Model-model Penilaian Berbasis Kompetensi$P A K$. Bandung : Bina Media Informatika.

[3] Iriyanti, Puji. (2004). Penilaian Unjuk Kerja. Yogyakarta : Depdiknas.

[4] KTSP SMK 9 Bandung Program Keahlian Patiseri.

[5] PERATURAN MENTRI NO. 20 TAHUN 2007. Tentang Standar Penilaian Pendidikan.

[6] Sardiman, A.M. (2011). Interaksi dan Motivasi Belajar Mengajar. Jakarta : Rajawali Pers.

[7] Setiyadi, Dwi. (2009). Performance assessment:Sebuah Dilema Penilaian Hasil Pembelajaran. Jurnal Pendidikan [Vol. 15, No. 1 Juni 2009: 1-15].

[8] UNDANG-UNDANG SISTEM PENDIDIKAN NASIONAL

[9] U.S. Wheat Asociate. (1981). Bakers Hand Book on Practical Baking. Jakarta : Djambatan.

[10] Van den Akker J. (1999(. Principles and Methods of Development Research. Pada J. Van den Akker, R. Branch, K. Gustafson, Nieven, dan T. Plomp (eds), Desugn Approaches and Tools in Education and Training (pp. 1-14). Dortrech: Klower Academic Publishers. 